\title{
Circular Economy, Sustainability, Retailers and Supply Chain Collaboration*
}

\author{
Vincenzo Tassinari $^{* *}$
}

\begin{abstract}
Today, large-scale retailers and industrial companies cannot ignore the impacts generated by their activity. Consequently, they are increasingly adopting behaviors attentive to issues related to corporate social responsibility. Italian distributors, driven by consumers, the regulatory system and stakeholders, also demonstrate a growing commitment to initiatives characterized by an orientation towards sustainability, which is often developed through supply chain collaborations.
\end{abstract}

Keywords: Circular Economy; Sustainability; Retailers; Collaboration; Global Competition; Global Markets, GS1-ECR

\section{Globalization and Corporate Sustainability}

The extraordinary economic and social development in the second half of the twentieth century has made the advantages of a stable and long lasting peace evident. However, this should not made us hide the existence of contextual limits and negative consequences. The abolishment of borders was accompanied by the reduction of barriers, which undoubtedly means more freedom but also less protection for consumers, citizens and people. Globalization then appeared with all its benefits, but also its imbalances. It is necessary to acknowledge a mechanism of distortion, where a small part of the global population is able to purchase, while the largest part is bound to purchase less and less, and that is the reason for a worrying stall of global economy. Some countries have benefited from this situation; for example, the countries of the far east, which have experienced a phase of tumultuous development in recent years, and an elite of advanced countries, which have found opportunities to strengthen their earnings. On the contrary, the difficulties of the poorest countries in the world (especially in Africa) and of the middle classes of advanced economies have increased.

Against this background the role of companies emerges, as possibly vital and decisive. Companies, as subjects creating social wealth, are and will always be required to be able to produce innovation, developing quality and profitability with fair prices on the market. At the same time, it is and will be necessary for companies to be able to be integrated into the society, giving positive answers to the market as well as to the social and environmental context in which they act.

\footnotetext{
* Invited Article

*** President, Sai Agricola. President of Coop Italia 1988-2013 (vincenzo.tassinari@ tenutedelcerro.it)
}

Edited by: Niccolò Cusano University

ISSN: 1593-0319

Tassinari, V. (2020). Circular Economy, Sustainability, Retailers and Supply Chain Collaboration. Symphonya. Emerging Issues in Management (symphonya.unicusano.it), (1), 129-135. 
Today, large-scale retailers, and industrial companies in general, cannot ignore the impacts generated by their activity, whether direct or indirect. The 'new way of thinking' they can adopt is an internal change that must take into account issues related to corporate social responsibility.

The European Commission stresses that corporate responsibility is not an additional element in relation to the fundamental activities of the enterprises themselves, but rather an activity linked to the management of the companies themselves.

Faced with the unsustainability of the current economic, social and environmental development model, on 25 September 2015 the United Nations approved the Agenda 2030 for sustainable development, with the related 17 objectives divided into 169 targets to be achieved by 2030 .

As underlined by Ban Ki-moon, Secretary General of the United Nations "The new agenda is a promise by leaders to all people everywhere. It is an agenda for people, to end poverty in all its forms - an agenda for the planet, our common home".

In particular, the objectives balance on some areas of crucial importance for humanity, which are:

- People: to end poverty and hunger, in all their forms and dimensions, and to ensure that all human beings can fulfil their potential in dignity and equality and in a healthy environment.

- Planet: to protect the planet from degradation so that it can support the needs of the present and future generations.

- Prosperity: to ensure that all human beings can enjoy prosperous in harmony with nature.

- Peace: to foster peaceful, just and inclusive societies which are free from fear and violence.

- Partnership: to mobilize the means required to implement the Agenda through a revitalized Global Partnership for Sustainable Development, based on a spirit of strengthened global solidarity.

The objectives are therefore in line with the three dimensions of corporate sustainability, which refers to:

1. economic sustainability - the creation of economic value for themselves and the community;

2. social sustainability - the satisfaction of social actors, viewed as the ability to ensure conditions of human well-being in a fair way;

3. environmental sustainability - environmental protection, that is evaluating the environmental impacts of processes, products, and services developed by the company.

A company's effectiveness therefore implies the assumption of a global responsibility concept based on strict compliance with the law, the creation of constructive relationships with all of society and respect for the environment. Of course, this does not mean losing sight of the importance of creating value and adequately compensating risk capital providers (Salvioni, 2003).

In summary CSR refers to the commitment to behave in a correct way, which goes beyond compliance with the obligations set by laws and individual ethical standards. CSR is a behavior that should influence all areas of governance and business management (Riboldazzi, 2018). 


\section{Sustainability in Italian Large-Scale Retailers}

After a decade of sudden growth (+33\% from 2003 to 2012), for six years now the Italian large-scale food distribution has had an overall sale area size that does not differ from 17 million square meters.

In 2017, the balance between openings and closings was negative for 700 stores. The slow recovery in consumption in recent years is not enough to reverse the progressive reduction of the distribution network in our country.

Indeed, the drop in the number of Italian retail outlets continues. The reduction continues to concern above all the sectors marked by the crisis in consumption (textiles-clothing, furnishings, printed paper, DIY) and smaller specialized stores, both food and non-food.

On the other hand, e-commerce is confirmed as the most dynamic sector of Italian retail. In our country, ecommerce turnover grows for the thirteenth consecutive year $(+11 \%)$, reaching the record figure of 30.5 billion euros, according to the measurements and projections of the Nexi Observatory (Coop Report, 2019).

Therefore, the progressive reduction in the number of stores continues, while the sector is being renewed in terms of new formats, openings and commercial networks. With reference to consumption, Italian consumers require innovation, but also tradition, reassurance and attention towards sustainability.

In this scenario, retailers demonstrate dynamic behavior, seeking differentiation opportunities and offering services that interpret the (changing) needs of consumers.

In this regard, the awareness of the importance of an orientation towards sustainability is increasingly evident in distribution companies.

Following the Elkington approach (1997) it is possible to evaluate the sustainability actions of Italian distribution companies in relation to the profit, people and planet dimensions.

As regards profit, large-scale retailers constantly strive to develop innovation and quality offers, spreading and managing numerous stores/format with specific store brands.

The stores, the offer and the retailing mix are often renewed with attention to efficiency, to contain costs and improve the quality of the service.

Thus, the ability to generate profit and value can also be achieved thanks to improvements in the efficiency of business processes and can be linked to the ability of companies to manage a complex system of competitive strategic alliances to balance the dimensional advantages with those related to specialization.

As regards to efficiency, these were also achieved thanks to the implementation of new technologies and systems often developed with supply chain collaboration logics (e.g., advanced CRM, cross-docking, etc.).

The commitment of distributors in new markets (insurance, fuel, pharmaceuticals, etc.) should also be considered to expand the offer opportunities always with a view to profit and value.

In relation to the people dimension, retailers are increasingly committed to guaranteeing safety, health, well-being, equal opportunities, the adequate enhancement of workers, and the organization of training activities aimed at updating and developing the skills and professionalism of employees.

Consumers are at the center of the people dimension. In this regard, there are important initiatives such as the offer of safe, quality, convenient products and 
dedicated services (think of activation of listening services, development of retraceability tools for product identification, reserved offers and promotions, certifications for food safety and supply chain traceability).

With reference to the community, the commitment of distributors is qualified in supporting the territory, the local community, culture and education, developing social or solidarity initiatives, many of which born from relationships with the institutions of the individual territories. Examples include activities such as redistribution of surpluses to charitable structures, donations to individuals with a social purpose, sale of fair trade goods, financing of scholarships, etc.

As for the environmental dimension, the large distributors reveal a commitment to the development of processes, activities, products and services, in order to reduce impacts on the environment.

In fact, more than in the rest of Europe, a strong sensitivity towards the "green" theme seems to have developed in our country, to the point that the environment is experienced as the key to individual well-being. As many as 9 out of 10 Italians (Eurobarometer) believe that living in a healthy environment is a fundamental condition for achieving a high quality of life.

This is a significantly higher percentage than the other countries, which documents how in Italy we have gone from simple good intentions to a widespread ecological awareness.

According to a survey carried out by the Piepoli Institute, the Italians have specifically changed their mobility model, habits at home and even food consumption. Organic, health-conscious or brown foods (flour and wholegrain products) end up in the dish more and more often. The purchase is increasingly influenced by the label that certifies the sustainability and ethics of the product, its production with techniques that respect the environment, that preserve natural resources and that protect the dignity of work and territories (Coop Report, 2019).

Thus, there is a strong commitment by companies to activities related to the environmental dimension of sustainability. Firms have taken several actions. Among these: the reduction of waste, the recycling of materials, the use of renewable energy, the reduction and conservation of energy and natural resources used for the exercise of commercial functions, the inclusion of careful green product lines, the optimization of mileage, the use of more efficient vehicles, the reuse of clear water, etc.

Moreover, the large distributors can promote, through their policies, environmental respect behaviors along the entire value chain, involving in particular suppliers and customers so that they too behave in compliance with the values of sustainability.

\section{GS1 Italy-ECR, Sustainability and Supply Chain Collaboration}

ECR Italia was born in 1993 as a joint association between industrial companies and distribution companies. Its activity is aimed at process innovation for the achievement of improvement objectives in terms of supply chain efficiency, the reduction of interface costs and the transfer of value to the consumer.

ECR Italia also aims to encourage the adoption of new relationship models between companies and spread a new managerial culture and a common language. ECR Italia is part of the 21 national organizations in Europe that make up the ECR Community, 
or the body that takes care of the diffusion in Europe of techniques, tools and methods of strategic/operational interface between industry and distribution and between them and the final consumer.

In 2004 it joined GS1 Italy, which represents the international body in Italy that coordinates the dissemination and correct implementation of the GS1 standard, i.e., the most widespread and representative system used for the development of technical tools to support world trade. GS1 Italy has 35,000 associated companies ${ }^{1}$.

Among the production companies associated with ECR it is possible to list the following ones: Barilla, Bauli, Beiersdorf, Bic Italia, Bolton Group, Cameo, Carapelli Firenze, Carlsberg Italia, Coca-Cola HBC Italia, Colgate Palmolive, Conserve Italia, Danone, Davide Campari Milano, Elah Dufour, Eridania Italia, Fater, Ferrarelle, Ferrero, FHP, GlaxoSmithKline, Granarolo, Heineken Italia, Henkel Italia, Johnson \& Johnson, Kellogg Italia, Kimberly-Clark, L'Oréal Italia, La Doria, Luigi Lavazza, Mondelez Italia, Montenegro, Muller, Nestlé Italiana, Parmalat, Perfetti Van Melle Italia, Procter \& Gamble, S.C. Johnson Italy, Sperlari, Star Stabilimento Alimentare, and Unilever.

On the other hand, Auchan, Autogrill Italia, Carrefour-GS, Conad, Coop Italia, Crai, D.It Distribuzione Italiana (Sigma), Despar Italia, Esselunga, Metro Italia, Selex, and VéGé Retail are the associated retailers.

The ECR Italia aim is therefore to promote the improvement of the efficiency and effectiveness of manufacturers and distributors of consumer goods, in their mutual relations and in their relations with other partners in the reference chains, in order to best meet consumer expectations.

Already in 2002 ECR Italia had opened a working table on the topic of social responsibility, defining it as the set of rules through which a company operates in the market, respecting the well-being of a large group of stakeholders, including workers, business partners, the community and the environment, safeguarding long-term business sustainability.

The potential areas of collaboration that the association had defined were the following: food safety, suppliers' working standards, waste/pollution reduction, responsibility for the product towards the consumer, transport optimization, fair trade /green label and ethical management of commercial relationships.

In recent years, the issue of sustainability has entered forcefully into the priorities of the companies associated with GS1 Italy and on the basis of pressures from consumers, the regulatory system and investors, GS1 Italy has developed several projects whose analysis allows us to understand some initiatives that Italian companies are tackling to give concrete answers on sustainability.

These include the optimal chain reorganization project and Atlante, the intermodal transport, the surplus food project and the Ecologistico2 project.

The optimal chain reorganization project supports the optimization of spaces and the saturation of vehicles to contain costs and logistic impacts.

Atlante is the tool that allows companies to have an overview of the national distribution network, in order to provide asset and transport sharing practices. Companies can understand the concentration and dispersion rate of the various logistical nodes in the area and analyze in depth the real opportunities for collaboration and optimization along the supply chain. The main advantages associated with the project are: reduction of transport costs, reduction of $\mathrm{CO}_{2}$ 
emissions and positive impact on environmental sustainability, reduction of maintenance costs and improvement of the quality of the logistics service.

Another project linked to the previous one is intermodal transport. The goal is to aggregate the volumes of goods of different companies and encourage the development of the railway transport. The project highlights that $30 \%$ of road trips made by consumer goods can be converted by rail allowing a 30\% reduction in emissions (with a reduction of 70 thousand tons of $\mathrm{CO}_{2} /$ year).

Ecologistico 2 also allows calculating the $\mathrm{CO}_{2}$ emissions produced by the transport and warehouse activities of a logistics network defined by the company. This tool allows companies to simulate different scenarios and to understand how different variables (types of vehicles, fuels, mode of transport, energy mix) influence the environmental impact of logistics, in order to implement improvement actions. The surplus food project works on product waste and develops on three dimensions to which actions that businesses can undertake are linked:

- Prevention: the goal is to eliminate the causes that generate surpluses.

- Redistribute the residual surplus considering actions such as donations, liquidation houses and animal feed.

- Recycle / Recover: i.e. adopt methods to reduce landfill disposal, such as anaerobic digestion, composting, and recovery of cooking oils should be pursued.

Numerous other projects have been developed by ECR and the joint industrydistribution effort (Fast Perfect Order, collaborative CRM, Shrinkage, Vendor Managed Inventory, etc.) and others are under development, underlining the importance of collaboration between companies for achieving of effectiveness and efficiency in corporate management, in line with the expectations of consumers and society.

\section{Bibliography}

Benioff, M., \& Adler, C. (2007). The Business of Changing the World: Twenty Great Leaders on Strategic Corporate Philanthropy. New York: McGraw-Hill.

Brondoni, S. M. (2008). Market-Driven Management, Competitive Space and Global Networks. Symphonya. Emerging Issues in Management (symphonya.unimib.it), (1), 14-27.

http://dx.doi.org/10.4468/2008.1.02brondoni

Brondoni, S. M. (2019). Shareowners, Stakeholders \& the Global Oversize Economy. The CocaCola Company Case. Symphonya. Emerging Issues in Management (symphonya.unicusano.it), (1), 16-27. http://dx.doi.org/10.4468/2019.1.02brondoni

Brondoni, S. M., \& Mosca, F. (2017). Ouverture de 'Integrated Corporate Social Responsibility'. Symphonya. Emerging Issues in Management (symphonya.unimib.it), (1), 1-6.

http://dx.doi.org/10.4468/2017.1.01ouverture

Civera, C. \& Freeman, R. E. (2019). Stakeholder Relationships and Responsibilities: A New Perspective. Symphonya. Emerging Issues in Management (symphonya.unicusano.it), (1), 40-58. http://dx.doi.org/10.4468/2019.1.04civera.freeman

Crane, A., Matten, D., \& Spence, L. J. (eds.) (2008). Corporate Social Responsibility: Readings and Cases in Global Context. London: Routledge.

Dahlsrud, A. (2008). How Corporate Social Responsibility is Defined: An Analysis of 37 Definitions. Corporate Social Responsibility and Environmental Management, 15(1), 1-13.

http://dx.doi.org/10.1002/csr.132 
Elkington, J. (1997). Cannibals with Forks: The Triple Bottom Line of $21^{\text {st }}$ Century Business. Oxford: Capstone.

Freeman, R. E. (2010). Strategic Management: A Stakeholder Approach. Cambridge: Cambridge University Press.

Freeman, R. E., \& Dmytriyev, S. (2017). Corporate Social Responsibility and Stakeholder Theory: Learning From Each Other. Symphonya. Emerging Issues in Management (symphonya.unimib.it), (2), 7-15.

http://dx.doi.org/10.4468/2017.1.02freeman.dmytriyev

Henriques, A., \& Richardson, J. (eds.) (2004). The Triple Bottom Line: Does it All Add Up? London: Earthscan.

http://dx.doi.org/10.1111/j.0045-3609.2005.00011.x

Javalgi, R., \& Ramsey, R. (2001). Strategic Issues of E-Commerce as an Alternative Global Distribution System. International Marketing Review, 18(4), 376-391.

http://dx.doi.org/10.1108/02651330110398387

Riboldazzi, S. (2015). Global Markets and Development Policies in Large-Scale Retailers. Symphonya. Emerging Issues in Management (symphonya.unimib.it), (5), 8-28.

http://dx.doi.org/10.4468/2015.5.02riboldazzi

Riboldazzi, S. (2018). Sustainable Development and Environmental Sustainability in Large-Scale Retailers. Symphonya. Emerging Issues in Management (symphonya.unimib.it), (1), 127-138.

http://dx.doi.org/10.4468/2018.1.10riboldazzi

Salvioni, D. M. (2003). Corporate Governance and Global Responsibility. Symphonya. Emerging Issues in Management (www.unimib.it/symphonya), (1), 44-54.

http://dx.doi.org/10.4468/2003.1.05salvioni

Salvioni, D. M., \& Gennari, F. (2017). CSR, Sustainable Value Creation and Shareholder Relations. Symphonya. Emerging Issues in Management (symphonya.unimib.it), (1), 36-49.

http://dx.doi.org/10.4468/2017.1.04salvioni.gennari

Valor, C. (2005). Corporate Social Responsibility and Corporate Citizenship: Towards Corporate Accountability. Business and Society Review, 110(2), 191-212.

Zeyen, A., Beckmann, M., \& Wolters, S. (2016). Actor and Institutional Dynamics in the Development of Multi-Stakeholder Initiatives. Journal of Business Ethics, 135(2), 341-360.

http://dx.doi.org/10.1007/s10551-014-2468-1

\section{Notes}

${ }^{1}$ For more details, see http://gs 1it.org/chi-siamo/ecr-italia/. 